\title{
46 GEOCHRONOLOGY OF BASALTIC ROCKS RECOVERED BY DSDP LEG 41, EASTERN ATLANTIC OCEAN
}

\author{
Robert A. Duncan, School of Oceanography, Oregon State University, Corvallis, Oregon, \\ and \\ Everett D. Jackson, U.S. Geological Survey, Menlo Park, California
}

\section{INTRODUCTION}

Attempts at obtaining reliable $\mathrm{K}-\mathrm{Ar}$ age determinations on igneous material collected from the ocean floor have been complicated by nonideal crystallization and subsequent alteration in the submarine environment. Magma erupted onto the ocean floor under a kilometer or more of seawater may be rapidly quenched so that some amount of radiogenic argon inherited from the magma's source region is retained, leading to an erroneously old age of crystallization. Dalrymple and Moore (1968) and Dymond (1970), among others, have shown that this effect is important in the outermost few centimeters of pillow lavas, but for more slowly cooled, coarser-grained basalts, sufficient degassing has occurred during crystallization that excess argon is probably not significant.

Radiogenic argon formed after crystallization from the natural decay of ${ }^{40} \mathrm{~K}$ to ${ }^{40} \mathrm{Ar}$ may be lost either by low-temperature alteration (conversion of primary mineral phases and interstitial matrix to secondary clay minerals and zeolites that, owing to their looser structure, "leak" argon) or from glass which has an unpredictable argon retentivity because of its amorphous structure. A third problem results from addition of potassium to the sample from seawater, leading to an underestimate of the sample age (Seidemann, 1976). These three effects must be considered in attempting $\mathrm{K}-\mathrm{Ar}$ age determinations on DSDP basalts.

For the present study, basaltic material was provided from near the bottom of the holes drilled at Sites 367 and 368 of Leg 41 . We selected samples for geochronology on the basis of microscopic examination. Samples were eliminated because of extensive lowtemperature alteration or presence of devitrified glass. None of the selected samples met the usual criteria, but four samples appeared sufficiently fresh to attempt age determinations. Conventional $\mathrm{K}-\mathrm{Ar}$ age determinations were performed for the four whole-rock samples. The results of these analyses appear in Table 1 and follow the techniques described by Dalrymple and Lanphere (1969).

Ages on additional aliquants of these samples were then determined by the ${ }^{40} \mathrm{Ar} /{ }^{39} \mathrm{Ar}$ total fusion technique (Merrihue and Turner, 1966). In this method, samples are irradiated in a fast neutron flux (USGS TRIGA reactor in Denver, Colorado). A proportion of ${ }^{39} \mathrm{~K}$ in the samples is converted to ${ }^{39} \mathrm{Ar}$. Because a monitor sample of known age is also irradiated with each batch of unknowns, the "conversion efficiency," expressed as the parameter $J$, can be measured. Argon is then extracted in the conventional manner and the ratios of four isotopes $\left({ }^{40} \mathrm{Ar},{ }^{39} \mathrm{Ar},{ }^{37} \mathrm{Ar}\right.$, and $\left.{ }^{36} \mathrm{Ar}\right)$ are measured by gas-source mass spectrometer. The sample age is then calculated from the isotopic ratios, the $J$ parameter determined from the monitor sample and known decay constants. Particulars of this method appear in Dalrymple and Lanphere (1971). Results are presented in Table 2 .

To offset the inconvenience of sample irradiation, this method offers several advantages over the conventional method. All measurements are determined on a single aliquant of the sample $\left({ }^{39} \mathrm{Ar}\right.$ directly measures the potassium content), which eliminates the problem of obtaining chemically identical aliquants from inhomogeneous samples. It also follows that a much smaller sample weight can be used-an advantage when sample quality and quantity are low. Perhaps the most attractive aspect of this method lies in the ability to investigate the distribution of radiogenic argon within a sample by heating in ever-increasing temperature increments-the stepwise, or incremental heating technique. Ideally, ages measured from the isotopic compositions of successive fractions of gas from a heated sample should be identical, producing a plateau on a plot of age versus temperature or fraction of gas released. Commonly, radiogenic argon and artificially produced ${ }^{39} \mathrm{Ar}$ have been lost or redistributed among the various melting phases so that gas fractions yield nonuniform ages. The incremental heating mode has been used on two samples, one each from Sites 367 and 368. Results appear in Table 3.

\section{RESULTS AND DISCUSSION}

\section{Site 367}

Site 367 is located in the Cape Verde Basin, southeast of the Cape Verde Islands and within the magnetic quiet zone along the eastern margin of the Atlantic Ocean. Basalt was recovered at this site after penetration of a 1153-meter sedimentary section. Reddishbrown argillaceous limestone, marl, and claystone that overlie the basalt are Upper Jurassic but not older than Oxfordian age (see Site Chapter 367, this volume). Samples from Cores $367-38$ and $367-39$ are nearly aphyric fine-grained vesicular basalts composed principally of plagioclase and pyroxene, which have been partially replaced by smectite, calcite, and pyrite, 
TABLE 1

Leg $41 \mathrm{~K}$-Ar Whole-Rock Ages

\begin{tabular}{|c|c|c|c|c|}
\hline $\begin{array}{l}\text { Sample } \\
\text { (Interval } \\
\text { in } \mathrm{cm} \text { ) }\end{array}$ & $\% \mathrm{~K}_{2} \mathrm{O}$ & $\begin{array}{c}\operatorname{Rad}^{40} \mathrm{Ar} \\
\left(\times 10^{-11} \mathrm{~mol} / \mathrm{g}\right)\end{array}$ & $100 \times \frac{\mathrm{Rad}^{40} \mathrm{Ar}}{\text { Total }^{40} \mathrm{Ar}}$ & Age (m.y.) \pm 1 S.D. \\
\hline $367-39-2$, & $0.339,0.340$ & 4.7421 & 43.6 & $92.0 \pm 1.6$ \\
\hline $70-71$ & $\{0.345,0.338$ & 4.5602 & 69.8 & $88.5 \pm 0.8$ \\
\hline $368-60-6$ & $0.400,0.388$ & 1.1287 & 46.5 & $19.3 \pm 0.3$ \\
\hline $30-32$ & $\{0.399,0.392$ & 1.0984 & 44.4 & $18.7 \pm 0.3$ \\
\hline $\begin{array}{r}368-60-6, \\
119-121\end{array}$ & $\left\{\begin{array}{l}0.638,0.637 \\
0.635,0.638\end{array}\right.$ & 1.5373 & 44.6 & $16.3 \pm 0.3$ \\
\hline $368-61-4$ & $0.413,0.413$ & 1.1020 & 47.4 & $18.1 \pm 0.3$ \\
\hline $82-84$ & $\{0.405,0.408$ & 1.1343 & 24.7 & $18.6 \pm 0.6$ \\
\hline
\end{tabular}

TABLE 2

Leg $41{ }^{40} \mathrm{Ar} /{ }^{39} \mathrm{Ar}$ Total Fusion Ages

\begin{tabular}{|c|c|c|c|c|c|c|c|c|}
\hline $\begin{array}{c}\text { Sample } \\
\text { (Interval } \\
\text { in } \mathrm{cm} \text { ) }\end{array}$ & ${ }^{40} \mathrm{Ar} /{ }^{39} \mathrm{Ar}$ & ${ }^{37} \mathrm{Ar}^{39} \mathrm{Ar}^{\mathrm{a}}$ & ${ }^{36} \mathrm{Ar} /{ }^{39} \mathrm{Ar}$ & $J^{\mathrm{b}}$ & $\begin{array}{c}{ }^{40} \mathrm{Ar}_{\mathrm{rad}} \\
(\%)\end{array}$ & $\begin{array}{c}{ }^{36} \mathrm{Ar}_{\mathrm{Ca}} \\
(\%)\end{array}$ & $\begin{array}{c}{ }^{39} \mathrm{Ar}_{\mathrm{Ca}} \\
(\%)\end{array}$ & Age (m.y.) \pm 1 S.D. \\
\hline $\begin{array}{l}367-39-2 \\
70-71\end{array}$ & 28.7 & 11.9 & 0.052 & 0.00388 & 49.7 & 6.2 & 0.8 & $102.4 \pm 2.0$ \\
\hline $\begin{array}{l}368-60-6, \\
30-32\end{array}$ & 9.8 & 11.1 & 0.030 & 0.00483 & 19.6 & 10.2 & 0.7 & $17.6 \pm 1.1$ \\
\hline $\begin{array}{l}368-60-6, \\
119-121\end{array}$ & 7.2 & 8.3 & 0.019 & 0.00483 & 30.1 & 11.8 & 0.5 & $19.7 \pm 0.5$ \\
\hline $\begin{array}{l}368-61-4, \\
82-84\end{array}$ & 5.3 & 12.3 & 0.014 & 0.00483 & 41.0 & 24.0 & 0.8 & $19.8 \pm 0.6$ \\
\hline
\end{tabular}

${ }^{\mathrm{a} C o r r e c t e d ~ f o r ~}{ }^{37} \mathrm{Ar}$.

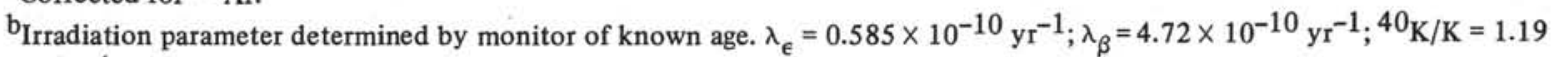
$\times 10^{-4} \mathrm{~mol} / \mathrm{mol}$.

TABLE 3

Leg 41 Ages from $40 \mathrm{Ar} /{ }^{39} \mathrm{Ar}$ Incremental Heatings

\begin{tabular}{|c|c|c|c|c|c|c|c|c|}
\hline $\begin{array}{c}\text { Sample } \\
\text { (Interval in } \mathrm{cm} \text { ) } \\
\text { and Temp. }\left({ }^{\circ} \mathrm{C}\right)\end{array}$ & ${ }^{40} \mathrm{Ar} /{ }^{39} \mathrm{Ar}$ & ${ }^{37} \mathrm{Ar} /{ }^{39} \mathrm{Ar}^{\mathrm{a}}$ & ${ }^{36} \mathrm{Ar} /{ }^{39} \mathrm{Ar}$ & $\begin{array}{c}{ }^{39} \mathrm{Ar}^{\mathrm{b}} \\
(\%)\end{array}$ & $\begin{array}{c}{ }^{40} \mathrm{Ar}_{\mathrm{rad}} \\
(\%)\end{array}$ & $\begin{array}{c}{ }^{36} \mathrm{Ar}_{\mathrm{Ca}} \\
(\%)\end{array}$ & $\begin{array}{c}{ }^{39} \mathrm{Ar}_{\mathrm{Ca}} \\
(\%)\end{array}$ & $\begin{array}{l}\text { Age (m.y.) } \\
\pm 1 \text { S.D. }\end{array}$ \\
\hline $\begin{array}{l}367-39-2 \\
70-71\end{array}$ & $J=0.00388$ & & & & & & & \\
\hline 400 & 88.7 & 2.8 & 0.242 & 1 & 19.7 & 0.3 & 0.2 & $123.9 \pm 6.3$ \\
\hline 525 & 24.9 & 4.3 & 0.028 & 14 & 68.5 & 4.2 & 0.3 & $121.2 \pm 1.8$ \\
\hline 650 & 23.9 & 9.2 & 0.034 & 20 & 61.0 & 7.4 & 0.6 & $104.6 \pm 1.7$ \\
\hline 775 & 22.0 & 11.6 & 0.025 & 23 & 70.2 & 12.4 & 0.7 & $110.7 \pm 1.6$ \\
\hline 900 & 19.9 & 6.2 & 0.023 & 24 & 68.5 & 7.4 & 0.4 & $97.7 \pm 1.4$ \\
\hline Fusion & 27.9 & 3.7 & 0.061 & 18 & 45.9 & 16.4 & 2.3 & $94.9 \pm 2.0$ \\
\hline \multicolumn{9}{|l|}{ Total gas age 105} \\
\hline $\begin{array}{l}368-60-6, \\
30-32\end{array}$ & $J=0.00483$ & & & & & & & \\
\hline 400 & 85.7 & 2.7 & 0.293 & 4 & -0.8 & 0.3 & 0.2 & $-6.1 \pm 9.0$ \\
\hline 525 & 14.8 & 3.2 & 0.041 & 13 & 20.1 & 2.1 & 0.2 & $26.9 \pm 1.4$ \\
\hline 650 & 5.0 & 8.8 & 0.012 & 40 & 42.8 & 19.7 & 0.6 & $19.6 \pm 0.5$ \\
\hline 750 & 231.3 & 4.6 & 0.720 & 8 & 8.2 & 0.2 & 0.3 & $166.2 \pm 18.7$ \\
\hline 900 & 10.4 & 3.2 & 0.028 & 18 & 22.6 & 3.1 & 0.2 & $21.3 \pm 1.0$ \\
\hline Fusion & 12.6 & 61.6 & 0.052 & 16 & 17.2 & 32.2 & 3.9 & $20.4 \pm 1.5$ \\
\hline Total gas age 19.8 & & & & & & & & \\
\hline
\end{tabular}

${ }^{a}$ Corrected for ${ }^{37}$ Ar decay.

${ }^{b}$ Percent released during increment. $\lambda_{\epsilon}=0.585 \times 10^{-10} \mathrm{yr}^{-1} ; \lambda_{\beta}=4.72 \times 10^{-10} \mathrm{yr}^{-1} ;{ }^{40} \mathrm{~K} / \mathrm{K}=1.19 \times 10^{-4} \mathrm{~mol} / \mathrm{mol}$.

and glass that has been converted to brown smectite. Vesicles are filled by calcite and clays. The single sample selected for geochronology (Table 4) was the freshest available to us. 
TABLE 4

Petrographic Data on Dated Leg 41 Basaltic Rocks

\begin{tabular}{|c|c|c|c|c|c|c|c|c|c|c|c|}
\hline \multirow[b]{2}{*}{$\begin{array}{l}\text { Sample } \\
\text { (Interval } \\
\text { in } \mathrm{cm} \text { ) }\end{array}$} & \multicolumn{3}{|c|}{$\begin{array}{c}\text { Phenocrysts } \\
\text { (or Microphenocrysts) }\end{array}$} & \multicolumn{2}{|c|}{ Vesicles } & \multicolumn{3}{|c|}{ Groundmass } & \multirow[b]{2}{*}{$\begin{array}{c}\text { Dominant } \\
\text { Texture }\end{array}$} & \multirow[b]{2}{*}{ Alteration } & \multirow[b]{2}{*}{ Remarks } \\
\hline & Mineral & Percent & $\begin{array}{l}\text { Average } \\
\text { Size } \\
(\mathrm{mm})\end{array}$ & Percent & $\begin{array}{c}\text { Average } \\
\text { Size } \\
(\mathrm{mm})\end{array}$ & Percent & & $\begin{array}{l}\text { Average } \\
\text { Size } \\
(\mathrm{mm})\end{array}$ & & & \\
\hline $\begin{array}{l}367-39-2 \\
70-71\end{array}$ & Plagioclase & 0.5 & $0.2 \times 1.5$ & 4.1 & 0.33 & 95.4 & & 0.05 & $\begin{array}{l}\text { Intersertal or } \\
\text { intergranular }\end{array}$ & $\begin{array}{l}75 \% \text { of vesicles filled } \\
\text { with calcite; } 25 \% \\
\text { partially filled with } \\
\text { brown smectite; glass } \\
\text { altered to olive-brown } \\
\text { smectite; some plagio- } \\
\text { clase altered to calcite } \\
\text { some pyroxene altered } \\
\text { to smectite; rare } \\
\text { chlorite }\end{array}$ & $\begin{array}{l}\text { Contained less ori- } \\
\text { ginal glass than } \\
\text { other samples avail- } \\
\text { able; opaque oxides } \\
\text { more evenly } \\
\text { distributed }\end{array}$ \\
\hline $\begin{array}{l}368-60-6 \\
30-32\end{array}$ & Aphyric & - & - & None & & $\begin{array}{l}\text { Plagioclase } \\
\text { Clinopyroxene } \\
\text { Glass } \\
\text { Opaques } \\
\text { Biotite }\end{array}$ & $\begin{array}{r}44.6 \\
35.6 \\
16.8 \\
2.5 \\
0.5\end{array}$ & $\begin{array}{l}0.2 \times 1.0 \\
0.8 \\
1.0 \\
0.2 \\
0.2\end{array}$ & Diabasic & $\begin{array}{l}\text { Glass mostly altered } \\
\text { to smectite; very } \\
\text { minor smectite alter- } \\
\text { ation in plagioclase } \\
\text { and pyroxene; very } \\
\text { few thin calcite } \\
\text { veins }\end{array}$ & $\begin{array}{l}\text { Glass in irregular } \\
\text { patches that contain } \\
\text { opaques and apatite }\end{array}$ \\
\hline $\begin{array}{l}368-60-6 \\
119-121\end{array}$ & Aphyric & - & - & None & & $\begin{array}{l}\text { Plagioclase } \\
\text { Clinopyroxene } \\
\text { Glass } \\
\text { Opaques } \\
\text { Biotite }\end{array}$ & $\begin{array}{r}47.5 \\
38.7 \\
10.5 \\
2.6 \\
0.7\end{array}$ & $\begin{array}{l}0.2 \times 1.5 \\
1.0 \\
1.3 \\
0.2 \\
0.2\end{array}$ & Diabasic & $\begin{array}{l}\text { Glass less altered } \\
\text { than } 30-32 \mathrm{~cm} \\
\text { interval }\end{array}$ & \\
\hline $\begin{array}{l}368-61-4 \\
82-84\end{array}$ & Aphyric & - & - & None & & $\begin{array}{l}\text { Plagioclase } \\
\text { Pyroxene } \\
\text { Glass } \\
\text { Opaques } \\
\text { Biotite }\end{array}$ & $\begin{array}{r}50.0 \\
38.3 \\
8.1 \\
2.6 \\
1.0\end{array}$ & $\begin{array}{l}0.2 \times 1.3 \\
1.0 \\
0.7 \\
0.4 \\
0.5\end{array}$ & Diabasic & $\begin{array}{l}\text { Small amounts of } \\
\text { smectite alter plagio- } \\
\text { clase pyroxene and } \\
\text { glass about equally }\end{array}$ & $\begin{array}{l}\text { Opaques scattered } \\
\text { evenly through } \\
\text { section }\end{array}$ \\
\hline
\end{tabular}

Conventional whole-rock $\mathrm{K}-\mathrm{Ar}$ ages (Table 1) for this sample indicate a Cretaceous age $(\sim 90$ m.y.). In view of the pervasive alteration, this must be considered a minimum age. Total fusion ${ }^{40} \mathrm{Ar} /{ }^{39} \mathrm{Ar}$ (Table 2) determines an age which is about $10 \%$ older-102.4 $\pm 2.0 \mathrm{~m} . \mathrm{y}$. Loss of ${ }^{39} \mathrm{Ar}$ from smectite between times of irradiation and fusion may partially explain the difference in ages determined by the two methods. If loss of radiogenic argon through alteration has led to an erroneously young age by the conventional method, then the total fusion age may be regarded as a truer estimate of the sample's age, but is still a minimum age.

More information about the distribution of ${ }^{40} \mathrm{Ar}$ and ${ }^{39} \mathrm{Ar}(=\mathrm{K})$ is provided by the incremental heating data in Table 3, which are illustrated in Figure 1. Six successive temperature fractions have been analyzed for their argon isotopic composition. Determined ages range from 124 to 95 m.y., generally decreasing from the low-temperature fractions to complete fusion. Figure $1 \mathrm{a}$ is an isochron diagram, plotting ${ }^{40} \mathrm{Ar}$ against ${ }^{39} \mathrm{Ar}$, each normalized to ${ }^{36} \mathrm{Ar}$. For ideal behavior, all components of a chemical system (i.e., lava) at time zero (crystallization) will possess atmospheric ${ }^{40} \mathrm{Ar} /{ }^{36} \mathrm{Ar}(=295.5)$. Because potassium is heterogeneously distributed among the various mineral phases, radiogenic argon accumulates at different rates. By separating temperature fractions, a range of ${ }^{40} \mathrm{Ar} /{ }^{36} \mathrm{Ar}$ and ${ }^{39} \mathrm{Ar} /{ }^{36} \mathrm{Ar}$ composition results. These compositions should be related linearly, with intercept ${ }^{40} \mathrm{Ar} /{ }^{39} \mathrm{Ar}=295.5$ and slope proportional to the age of the sample.

Figure 1a shows that this sample has not behaved ideally. Isotopic compositions from six temperature fractions scatter about the best fitting straight line (determined by York's, 1969, technique for correlated errors). The isochron age is $105.4 \pm 7.7 \mathrm{~m} . \mathrm{y}$. with intercept $298 \pm 25$. Even though the atmospheric composition is indistinguishable from the estimated intercept, the departure of compositions from the bestfit straight line suggests that radiogenic argon $\left({ }^{40} \mathrm{Ar}\right)$ and potassium $\left(={ }^{39} \mathrm{Ar}\right)$ have been lost or redistributed since crystallization. Hence this isochron age cannot be considered significant. The low-temperature fractions of the incremental heating which yield ages close to 122 m.y. may be the closest to the true age of the basalt. It is unlikely, however, that these ages are significant and our best estimate of the sample age remains that derived from overlying sediments (Upper Jurassic).

In plotting age against cumulative percent ${ }^{39} \mathrm{Ar}$ released, the so-called age spectrum diagram (Figure lb), no plateau age is discernible. The distinctive decrease in apparent age from low-temperature to hightemperature gas fractions may indicate ${ }^{39} \mathrm{Ar}$ recoil effects (Turner and Cadogan, 1974). In fine-grained rocks composed of K-rich and K-poor phases, recoil of ${ }^{39} \mathrm{Ar}$ from neutron bombardment may cause a transfer of ${ }^{39} \mathrm{Ar}$ from the $\mathrm{K}$-rich phases to the $\mathrm{K}$-poor phases. Because K-poor phases (e.g., pyroxene) generally retain argon to higher temperatures than K-rich phases (e.g., plagioclase, mesostasis), the irradiation-induced redistribution of ${ }^{39} \mathrm{Ar}$ increases apparent ages for lowtemperature gas fractions by increasing ${ }^{40} \mathrm{Ar} /{ }^{39} \mathrm{Ar}$ and decreases apparent ages for high-temperature gas fractions by decreasing ${ }^{40} \mathrm{Ar} /{ }^{39} \mathrm{Ar}$. Such redistribution of ${ }^{39} \mathrm{Ar}$ may have occurred during irradiation of this sample. If no ${ }^{40} \mathrm{Ar}$ has been lost prior to irradiation, a meaningful age may be obtained by combining all gas fractions (equivalent to a total fusion age). As ${ }^{40} \mathrm{Ar}$ loss 

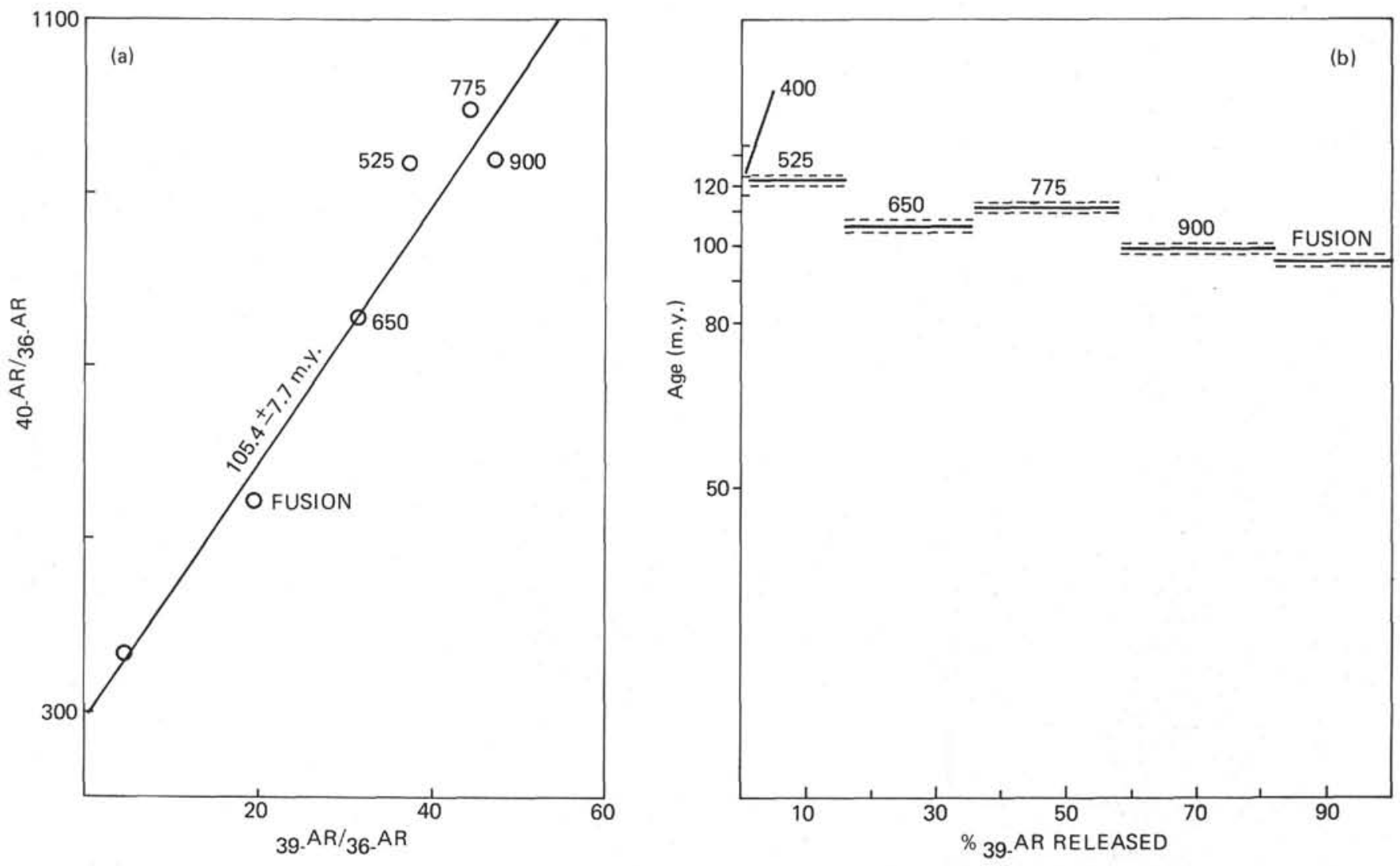

Figure 1. Incremental heating for Sample 367-39-2, 70-71 cm. (a) ${ }^{40} \mathrm{Ar}-{ }^{39} \mathrm{Ar}$ isochron, ${ }^{40} \mathrm{Ar} /{ }^{36} \mathrm{Ar}$, and ${ }^{39} \mathrm{Ar} /{ }^{36} \mathrm{Ar}$ for six temperature fractions are corrected for calcium and potassium interferences-uncertainties in age and intercept are 1 S. D. (York, 1969); (b) apparent ${ }^{40} \mathrm{Ar} /{ }^{39}$ Ar age versus fraction of ${ }^{39}$ Ar released--dashed lines are 1 S. D. for the apparent ages.

has probably occurred, the recombined total gas age of $105.1 \pm 1.8 \mathrm{~m} . \mathrm{y}$. is a minimum age.

\section{Site 368}

Site 368 is located northeast of the Cape Verde Islands on the Cape Verde Rise. Drilling at this site penetrated 985 meters of predominantly terrigenous sediments before intersecting three diabase sills interstratified with black shale. The shales are Upper Cretaceous in age (Site Chapter 368, this volume). The lithostratigraphic data suggest that this intrusive episode is related to the Miocene volcanic activity on the Cape Verde Islands and around Dakar, Senegal. Volcanic ash is also found in upper Miocene sediments of Cape Verde Rise (also Site 368), probably manifesting the same volcanic episode.

Three samples of diabase from the lower, thicker unit at Site 368 were chosen for geochronology. These rocks are much fresher than the sample collected from Site 367. They are medium- to coarse-grained aphyric basalts with diabasic texture (Table 4). Glass is abundant, but both the amount of glass and the extent of its smectite alteration decrease downward in the sill. There is some suggestion from our samples that grain size also increases downward (see Natland, this volume).

Conventional $\mathrm{K}$-Ar whole-rock ages indicate that the diabase recovered at Site 368 is of early Miocene age and thus postdates the Cretaceous sediments into which it must have been intruded. Two of the three samples (368-60-6, 30-32 $\mathrm{cm}$ and 368-61-4, 82-84 cm) yield reproducible ages and agree with one another at 18-19 m.y. (Table 1). The third yielded a slightly younger age, $16.3 \mathrm{~m} . y$. Total-fusion ${ }^{40} \mathrm{Ar} /{ }^{39} \mathrm{Ar}$ (Table 2) age determinations on the same three samples show a similar consistency, with slightly older mean age, 19.0 $\mathrm{m} . \mathrm{y}$. From the compatibility of conventional K-Ar ages with total-fusion ages, we conclude that ${ }^{39} \mathrm{Ar}$ loss after irradiation has not been a significant problem. Results of ${ }^{40} \mathrm{Ar} /{ }^{39} \mathrm{Ar}$ incremental heating for one sample from Site 368 appear in Table 3 and Figure 2. Disregarding the $400^{\circ} \mathrm{C}$ increment, in which fractionation of ${ }^{36} \mathrm{Ar}$ relative to ${ }^{40} \mathrm{Ar}$ has led to a negative age, and the $750^{\circ} \mathrm{C}$ increment, which required an additional clean-up so that its extreme age may also be due to fractionation, the remaining temperature steps indicate a Miocene to Oligocene age. Figure 2a plots the isotopic compositions of these fractions and the isochron resulting from the best-fit straight line to three of them $\left(525^{\circ} \mathrm{C}\right.$ increment is not used because of likely ${ }^{36} \mathrm{Ar}$ or ${ }^{39} \mathrm{Ar}$ loss). The isochron yields an age of $19.1 \pm 0.7 \mathrm{~m} . \mathrm{y}$. with an intercept of $301 \pm 4$, slightly above the atmospheric ${ }^{40} \mathrm{Ar} /{ }^{36} \mathrm{Ar}$. The plateau age developed by the three temperature increments (Figure 2b) is $20.2 \pm 1.0$ m.y., a weighted mean. Hence ages determined by the three methods are in good agreement and indicate an age of about 19 m.y. (early Miocene, Berggren, 1972). 

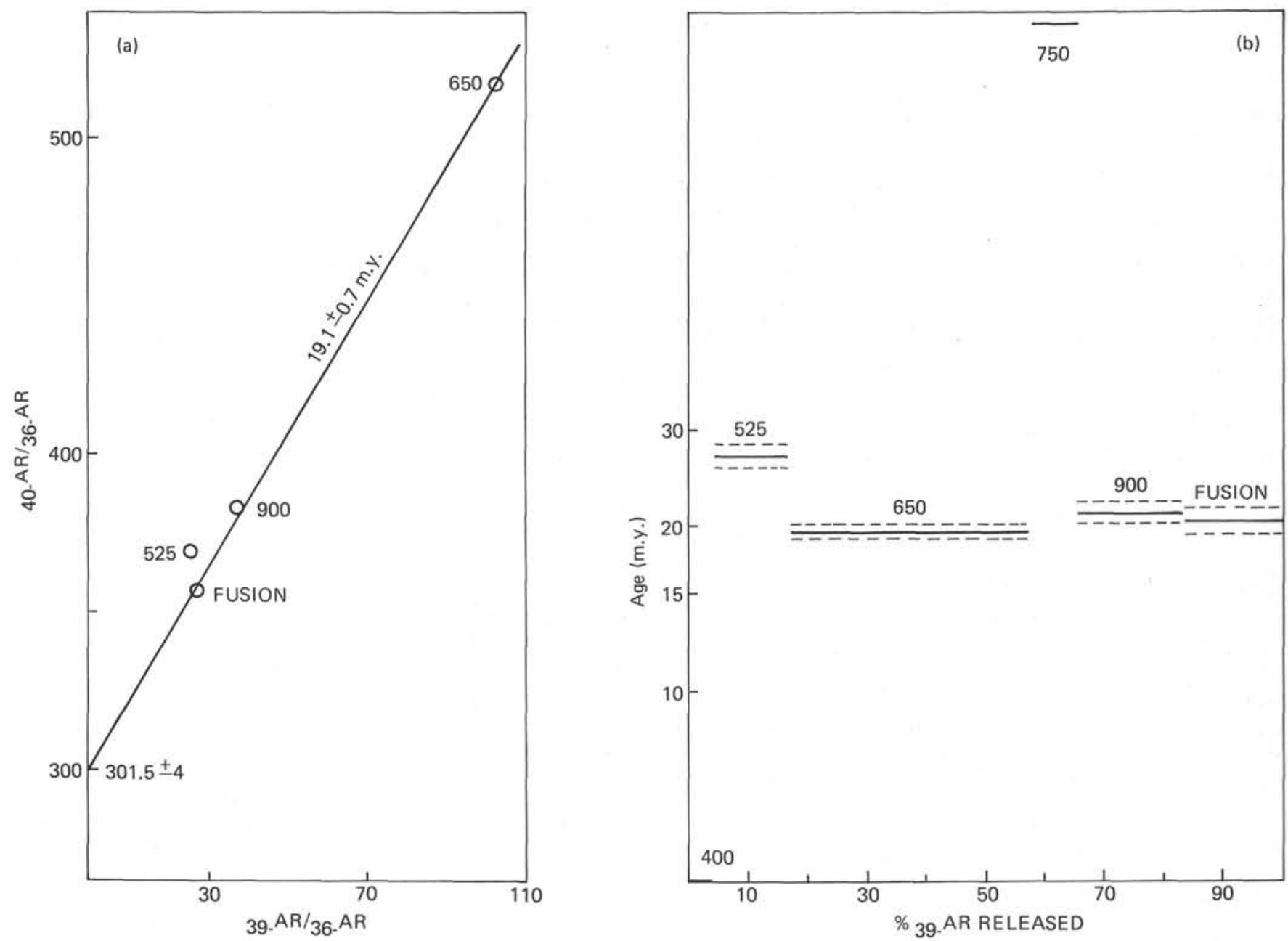

Figure 2. Incremental heating for Sample $368-60-6,30-32 \mathrm{~cm}$. (a) ${ }^{40} \mathrm{Ar}-{ }^{39} \mathrm{Ar}$ isochron, $40 \mathrm{Ar} /{ }^{36} \mathrm{Ar}$, and ${ }^{39} \mathrm{Ar} /{ }^{36} \mathrm{Ar}$ for four temperature fractions are corrected for calcium and potassium interferences-uncertainties in age and intercept are $1 S$. D. (York, 1969); (b) apparent ${ }^{40} \mathrm{Ar} /{ }^{39}$ Ar age versus fraction ${ }^{39}$ Ar released-dashed lines are $1 \mathrm{~S}$. D. for the apparent ages.

Alkalic volcanic rocks erupted in the Cape Verde Islands during Miocene and Quaternary times, last erupting in 1951 (see Dillon and Sougy, 1974, for a summary). Volcanic activity of a similar age occurred near Dakar, Senegal, and it is natural to include the submarine intrusions with this larger region of tectonic and volcanic activity. Dillon and Sougy (1974) suggest that the collision of the African plate with the Eurasian plate in Miocene time precipitated this volcanism. Alternatively, the volcanism may be a manifestation of plume activity (Morgan, 1972) which, because of the very slow movement of the African plate since Miocene time, has produced a restricted region of prolonged activity rather than a well-defined lineament.

In the Site 368 Summary (this volume) it is proposed that the uplift of the Cape Verde Rise, which occurred in the middle Miocene, was related to this volcanic activity. The age of the diabase sill in Site 368 indicates that the intrusive event somewhat predated the uplift and suggests that longer term thermal conduction may account for the uplift.

\section{ACKNOWLEDGMENTS}

We are grateful to G.B. Dalrymple who suggested this project and gave helpful advice. We thank J. Von Essen and S.E. Sims for technical assistance and G.P. Kraker for sample irradiations. J.V. Gardner kindly provided the samples. We also thank R.J. Fleck and J.V. Gardner for helpful comments in reviewing the manuscript.

\section{REFERENCES}

Berggren, W.A., 1972. A Cenozoic time scale-some implications for regional geology and paleobiogeography: Lethaia, v. 5, p. 195-215.

Dalrymple, G.B. and Lanphere, M.A., 1969. Potassiumargon dating: San Francisco (Freeman).

1971. ${ }^{40} \mathrm{Ar} /{ }^{39} \mathrm{Ar}$ technique of $\mathrm{K}-\mathrm{Ar}$ dating: $\mathrm{A}$ comparison with the conventional technique: Earth Planet. Sci. Lett., v. 12, p. 300-308.

Dalrymple, G.B. and Moore, J.G., 1968. Argon-40: Excess in submarine pillow basalts from Kilauea Volcano, Hawaii: Science, v. 161, p. 1132-1135. 
Dillon, W.P. and Sougy, J.M.A., 1974. Geology of West Africa and Canary and Cape Verde Islands. In Nairn, A.E.M. and Stehli, F.G. (Eds.), The ocean basins and margins: New York (Plenum Press), p. 315-390.

Dymond, J.R., 1970. Excess argon in submarine basalt pillows: Geol. Soc. Am. Bull., v. 81, p. 1229-1232.

Merrihue, C. and Turner, G., 1966. Potassium-argon dating by activation with fast neutrons: J. Geophys. Res., v. 71, p. 2852-2857.

Morgan, W.J., 1972. Deep mantle convection plumes and plate motions: Am. Assoc. Petrol. Geol. Bull., v. 56, p. 203-213.
Seidmann, D.E., 1976. K-Ar dates for basaltic rocks from Sites 319 and 321, Leg 34. In Yeats, R.S., Hart, S.R., et al., Initial Reports of the Deep Sea Drilling Project, Volume 34: Washington (U.S. Government Printing Office), p. $445-447$.

Turner, G. and Cadogan, P.H., 1974. Possible effects of ${ }^{39} \mathrm{Ar}$ recoil in ${ }^{40} \mathrm{Ar}-{ }^{39} \mathrm{Ar}$ dating. In Fifth Lunar Sci. Conf. Proc. (Suppl. 5, Geochim. Cosmochim. Acta): v. 2, p. 16011615.

York, D., 1969. Least squares fitting of a straight line with correlated errors: Earth Planet. Sci. Lett., v. 5, p. 320324. 